\title{
Wind Energy: \\ Legal Issues and Institutional Barriers
}

Lynde Coit
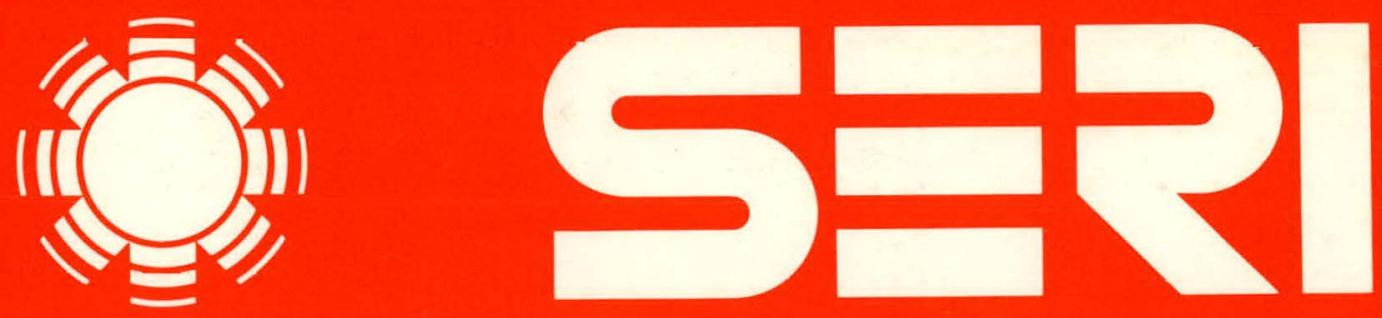

Solar Energy Research Institute A Division of Midwest Research Institute

1536 Cole Boulevard

Golden, Colorado 80401

Operated for the U.S. Department of Energy under Contract No. EG-77-C-01-4042

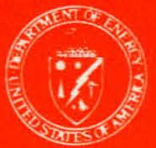




\section{DISCLAIMER}

This report was prepared as an account of work sponsored by an agency of the United States Government. Neither the United States Government nor any agency Thereof, nor any of their employees, makes any warranty, express or implied, or assumes any legal liability or responsibility for the accuracy, completeness, or usefulness of any information, apparatus, product, or process disclosed, or represents that its use would not infringe privately owned rights. Reference herein to any specific commercial product, process, or service by trade name, trademark, manufacturer, or otherwise does not necessarily constitute or imply its endorsement, recommendation, or favoring by the United States Government or any agency thereof. The views and opinions of authors expressed herein do not necessarily state or reflect those of the United States Government or any agency thereof. 


\section{DISCLAIMER}

Portions of this document may be illegible in electronic image products. Images are produced from the best available original document. 
Printed in the United States of America Available from:

National Technical Information Service

U.S. Department of Commerce

5285 Port Royal Roar

Springfield, VA 22161

Price:

Microfiche $\$ 3.00$

Printed Copy $\$ 5,25$

\section{NOTICE}

This report was prepared as an account of work sponsored by the United States Government. Neither the United States nor the United States Department of Energy, nor any of their employees, nor any of their contractors, subcontractors, or their employees, makes any warranty, express or implied, or assumes any legal liability or responsibility for the accuracy, completeness or usefulness of any information, apparatus, product or process disclosed, or represents that its use would not infringe privately owned rights. 
WIND ENERGY: $\angle E G A L$ ISSUES AND INSTITUTIONAL BARRIERS

LYNDE COIT

JUNE 1979

PREPARED UNDER TASTK 6223.20

- NOTICE -

This report was prepared as an account of work

This report was prepared as an account of work

sponsared hy the Unitert States Govemment. Neither the

United States nor the United States Departmenter their

Energy, nor any of their employees, nor any of their

contractors, subcontractors, or their employees, makes

any warranty, express or implied, or assumes any legal

liability or responsibility for the accuracy, completeness

or usefutiess of any infúrination, apparatus, produet of
process disclosed, or represents that its use would not

infringe privately owred rights.

\section{Solar Energy Research Institute}

1536 Cole Boulevard

Golden, Colorado 80401

A Division of Midwest Research Institute

Prepared for the

U.S. Department of Energy

Contract No. EG $\cdot 77 \cdot \mathrm{C} \cdot 01 \cdot 4042$ 


\section{FOREWORD}

This Wind Energy Legal Reconnaissance paper was prepared by the Solar Energy Research Institute to fulfill, in part, SERI's solar information dissemination function. This paper is part of the Market Development Branch Law Program, which in turn is a part of the overall program of the Technology Commercialization Division.

This is the second of five Legal Reconnaissance Papers sponsored by the SERI Law Program. The other four address (1) legal issues surrounding the commercialization of OTEC, (2) utilities and solar technologies, (3) municipal bonds as a method of accelerating public and municipal interest in solar energy, and (4) legal issues raised by the commercialization of SHAC devices. These five studies are meant to broadly survey the legal questions that are raised by either a specific solar technology (i.e., OTEC, WECS, and SHAC), or a potential barrier or incentive to the general commercialization of solar technologies (i.e., utilities and municipal bonds). It is hoped that these reconnaissance papers will be springboards for further, more detailed studies of some aspect of the general topic covered.

The author of this paper, Lynde Coit, is a law student at the Cornell Law School. He was a consultant to the Law Program during the summer and fall of 1978. The Law Program would like to acknowledge the editorial assistance provided this paper by Kevin O'Brien, a law clerk to the Law Program during the spring of 1979, and Professor Jan Laitos, a SERI consultant and visiting law professor.

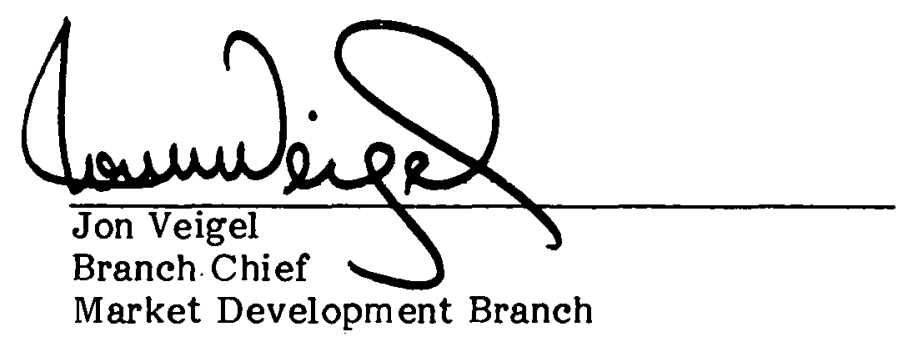

Approved for:

SOLAR ENERGY RESEARCH INSTITUTE

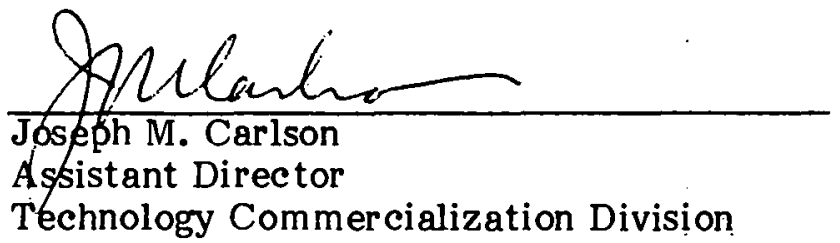




\section{TABLE OF CONTENTS}

Page

Abstract $\ldots \ldots \ldots \ldots \ldots \ldots \ldots \ldots \ldots \ldots \ldots \ldots \ldots \ldots \ldots \ldots \ldots \ldots \ldots \ldots \ldots$

Summary $\ldots \ldots \ldots \ldots \ldots \ldots \ldots \ldots \ldots \ldots \ldots \ldots \ldots \ldots \ldots \ldots \ldots \ldots \ldots \ldots \ldots$

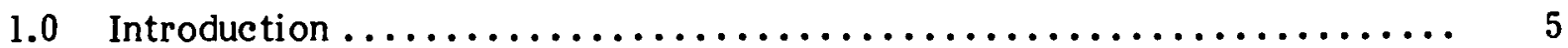

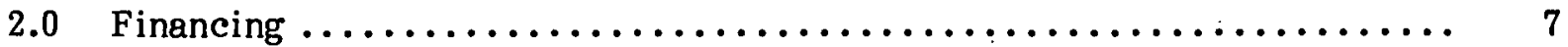

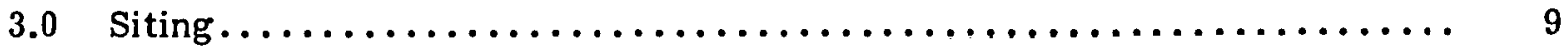

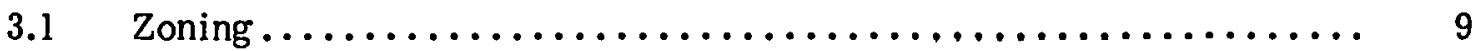

3.2 Guaranteed Access to Wind............................. 10

$3.3 \quad$ NEPA and Other Federal and State Statutes $\ldots \ldots \ldots \ldots \ldots \ldots \ldots \ldots 11$

3.4 Offshore Siting of WECS ........................... 12

$4.0 \quad$ WECS Operation $\ldots \ldots \ldots \ldots \ldots \ldots \ldots \ldots \ldots \ldots \ldots \ldots \ldots \ldots \ldots \ldots \ldots \ldots \ldots$

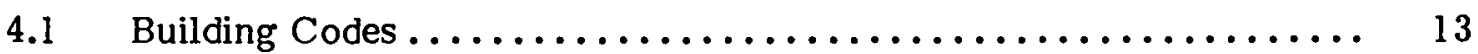

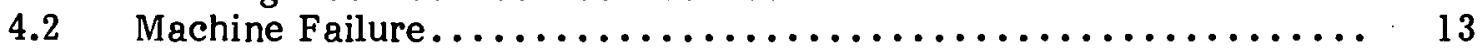

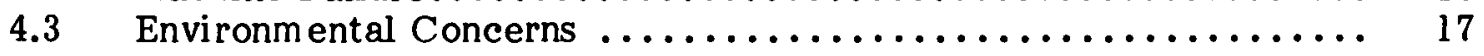

4.3.1 Microwave Interference................... 17

4.3.2 Climate Modification ..................... 17

4.3.3 Noise ............................... 17

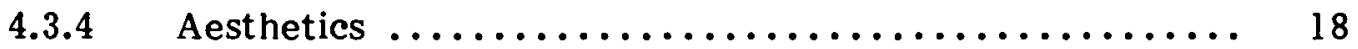

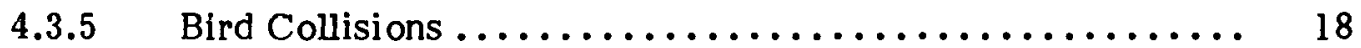

5.0 Conclusion $\ldots \ldots \ldots \ldots \ldots \ldots \ldots \ldots \ldots \ldots \ldots \ldots \ldots \ldots \ldots \ldots \ldots \ldots \ldots$

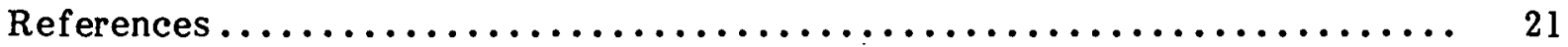




\begin{abstract}
The idea of harnessing the wind's energy is not a new one. Prior to World War II, over six million small windmills were built in the United States. Unfortunately, the development of cheaper fossil fuels during the postwar industrial boom resulted in the large-scale abandonment of wind generation devices. Suddenly, however, with the price of fossil fuels rising almost daily, wind energy has once again become an attractive energy al ternative.

Before the potential of wind energy can be realized, large-scale commercialization will have to occur. Standing in the way of commercial development are various institutional and legal barriers. These include (1) possible conflicts with existing zoning and other land-use planning schemes, (2) the question of guaranteeing access to the wind, (3) possible tort and environmental law issues raised by WECS operation, and (4) the critical problem of creating financial incentives. This paper discusses the implications of each of these issues and suggests solutions where practicable.
\end{abstract}


THIS PAGE INTENTIONALLY LEFT BLANK 


\section{SUMMARY}

The idea of harnessing the wind's energy is not a new one. Prior to World War II, over six million small windmills were built in the United States. Unfortunately, the development of cheaper fossil fuels during the postwar industrial boom resulted in the large-scale abandonment of wind generation devices. Suddenly, however, with the price of fossil fuels rising almost daily, wind energy has once again become an attractive energy al ternative.

Federal legislation includes wind within the definition of solar energy. Wind energy conversion is an important element in the nation's future energy policy. But before the potential of wind energy can be realized, large-scale commercialization will have to occur. Standing in the way of that commercial development are various legal and institutional barriers. The purpose of this paper is to identify those barriers, discuss their implications, and propose possible solutions.

Several legal issues are raised by large-scale wind energy development. The problems associated with machine siting and the impact of existing zoning schemes will be critical. Likewise, the need to guarantee access to the wind must be addressed before large-scale investment is possible. Finally, the tort and environmental law questions raised by the operation of huge arrays of wind machines are significant.

The major institutional barrier to large-scale wind energy development is financing. While wind energy conversion systems (WECS) are cost-effective over the long run in some circumstances, the initial investment cost is high. The financial institutions that control most of the money used for new construction are typically conservative in backing new technologies. And since WECS are only marginally cost-effective for most uses, a difference of a few percentage points in the interest rate charged a WECS installer can be crucial. Consequently, financial incentives from the government will be a much needed spur to commercial development.

Ultimately, public acceptance will be the key to large-scale WECS commercialization. Legal and economic institutions can be changed, but will do so only if pressured by an interested public. Thus, not until the public decides that wind is an attractive and viable energy alternative will the potential of wind power be fully realized. 
THIS PAGE INTENTIONALLY LEFT BLANK. 


\section{SECTION 1.0}

\section{INTRODUCTION}

"The atmosphere enveloping the earth is a rotating, regenerative thermal engine, stoked by radiant energy from the sun." [1] This engine converts about two percent of the energy received from the sun into mechanical energy in the form of wind [2], resulting in total power generation of about $3 \times 10^{17}$ kilowatts [3]. The total wind energy available over the land area of the United States, currently calculated to be $1.15 \times 10^{\mathrm{Y}} 4$ kilowatt hours [4], is conservatively estimated to have an electricity-generation potential of one trillion kilowatt hours annually by the year 2000 [5]. This is equivalent to 13.6 percent of the nation's projected annual demand for the year 2000 [6].

To harness this energy, over six million small windmills were built in the United States prior to World War II. These windmills were used to pump water and produce electricity for farms and homes throughout the Midwest and Southwest [7]. Unfortunately, the vast majority of these have fallen into disuse-rendered uneconomical by cheaper fossil fuels. When, however, in the fall of 1973 the Organization of Petroleum Exporting Countries (OPEC) quadrupled the price of petroleum [8], oil was no longer inexpensive and the United States' reliance on imports for nearly 50 percent of its petroleum [9] began to have ominous political overtones. Although the United States has vast amounts of coal, concern with the environmental degradation caused by burning coal [10] has increased the nation's interest in alternate, renewable forms of energy, including wind.

The Federal Solar Energy Research, Development and Demonstration Act of 1974 (SERDDA) [11] declares that it is the policy of the Federal Government to "pursue a vigorous and viable program of research and resource assessment of solar energy as a major source of energy for our national needs," and to "provide for the development and demonstration of practical means to employ solar energy on a commercial scale" [12]. The Act specifically includes wind within the meaning of solar energy [13]. President Carter's National Energy Plan provided that, "Wind systems can supply energy to small utilities, hydroelectric systems, and dispersed users of power" [14]. The National Energy Conservation Policy Act requires that states formulate residential energy conservation plans that include "devices to utilize ... windpower" [15] .

It is estimated that the cumulative savings between 1980 and 2000 that could result from the use of wind power would be the equivalent of 270 million to 4 billion barrels of oil in nuclear, coal, oil, and natural gas [16]. To achieve these savings, huge arrays of wind turbines and rapid implementation of wind technology will be necessary [17].

The purpose of this paper is to provide a survey of the legal barriers facing large scale implementation of wind energy conversion systems (WECS), and to outline some of the potential opportunities available through large scale commercialization. Wind energy will encounter many of the same problems met by the other solar technologies, but some of the problems, such as those generated by the active and potentially dangerous wind turbinie, are unlque to WECS.

Despite the popularity of wind machines [18] in the early part of this century [19], they seldom appear in early statutory or case law. Only California [20], Florida [21], Texas [22], and Nebraska [23] mentioned windmills in their statutes. Recently, however, some states have enacted laws providing incentives for taxpayers who purchase or build devices collecting energy from the wind [24]. For example, a new Nebraska statute 
permits certain municipalities to establish and regulate windmills [25]. Other legislation deals primarily with mechanics liens and the like, and not with issues directly concerning potential WECS developers.

The scarcity of cases involving windmills [26] suggests that their use in rural areas for traditional purposes will meet with no legal opposition. Legal problems will arise instead from deviations from these customary uses. Any attempt, therefore, to predict future legal issues must be made with an eye on technical innovations being proposed [27]. Conversely, it is important for those who would develop new wind-powered technologies to be aware of the legal framework within which they operate. Any emerging technology depends ultimately on positive public opinion for acceptance. Wind energy is now thought of positively by a public that knows little about it but wishes to have abundant energy and avoid environmental despoilation [28]. Those who attended the Second Workshop on Wind Energy Conversion Systems [29] feared that hasty implementation of WECS could eliminate the whole program [30]. The sort of legal imbroglios that have plagued the development of nuclear energy would certainly be a sevcre selbuck. Tlivugh many perceived barriers to large scale WECS exist, some of these serve leyilimate purposes. Therefore, one should not be too hasty in calling for their removal.

The legal issues will be presented roughly in the chronological order in which they would arise. Financing, siting, possible tort liability, and environmental problems are each discussed in turn. One topic which is not discussed is the interconnection between wind energy conversion and public utilities. This broad area has been treated in depth by other authors [31], and is generally beyond the scope of this article. 


\section{SECTION 2.0}

\section{FINANCING}

Present wind energy conversion systems in both small- and large-scale applications, although cost-effective over the long run in some circumstances [32], suffer from high initial costs. This problem is heightened because electricity generation from wind is a new technology whose ultimate economic viability has yet to be conclusively demonstrated [33]. Financial institutions that control most of the money used for new construction are typically conservative in backing new technologies [34]. Furthermore, because WECS presently are only marginally cost-effective for most uses, a difference of a few percentage points in the interest rate charged a WECS installer who finances through a loan can be crucial [35]. Financial incentives from the government might, therefore, accelerate the rate of WECS acceptance in the market place [36].

A number of states have enacted solar energy tax incentive laws [37]. These include income tax deductions [38] and credits [39]. Some of the states' tax provisions limit solar energy to "solar energy heating and cooling units" [40] and would thus not apply to wind machines. Others expressly include wind in the definition of solar technologies to which the incentives apply [41]. Still others contain ambiguous language, such as this definition of solar energy device: "any system which provides heating, cooling, electrical power or mechanical energy by means of collecting, transferring and storing solar generated energy" [42]. This definition arguably includes wind energy. It is likely that most states who neglected to include "wind" within their solar tax incentives did so by mistake and will correct this omission when it is brought to their attention.

Some states [43] require that the solar energy collecting device meet certain standards before it can qualify for tax incentives [44]. The lack of such standards for wind machines will be a major stumbling block in qualifying for favorable tax treatment. A prime concern of those involved with WECS marketing should therefore be the drafting and distribution of standards applicable to wind machines.

Most states, however, lack the resources required to provide truly effective tax incentives [45]. A study is currently being made ".... to identify the most effective forms of government economic incentives to commercialize large and small wind systems in various applications" [46]. Although there is little empirical data on the actual effectiveness of the state incentives, it seems fair to say that they of ten do not involve enough money to overcome consumer reluctance.

The Federal Government has the resources necessary to provide more effective financial incentives. For example, the Energy Tax Act of 1978 [47] provides tax credits for both hom eowners and businesses. Title I of the Act provides for a Residential Energy Credit, that applies to "wind energy for nonbusinesses residential purposes" [48]. The credit is directly deductible from the taxpayer's tax liability, thus reducing the amount he must pay; one dollar for each dollar of the credit. The total credit equals 30 percent of the first $\$ 2,000$ invested and 20 percent of the next $\$ 10,000$ [49]. This credit is nonrefundable (if the credit exceeds the taxpayer's total liability he cannot receive a rebate from the government), but any excess can be carried over to the next year and applied against that year's tax liability [50]. This credit should be helpful in offsetting the high initial cost of WECS. A wind machine costing $\$ 5,000$ would entitle the purchaser to a $\$ 1,200$ tax credit, greatly decreasing the time necessary for him to recoup his investment through reduced outside energy costs [51]. 
The Energy Tax Act, in Title III, also provides for a business investment tax credit "to encourage new energy technology" [52]. The additional tax credit may be directly subtracted from the business's tax liability, and any excess (credit greater than liability) is directly refundable to the business [53]. The credit may be used by those who spend money on "wind energy property" [54]. The availability of this credit should spur utilities and industries to consider wind energy generation [55].

A companion bill, the National Energy Conservation Policy Act of 1978 [56], provides for secondary financing and loan insurance for energy conserving improvements and systems "designed to utilize wind energy" [57]. The secondary financing is to be provided by the Federal Home Loan Mortgage Corporation and the Federal National Mortgage Association [58]. The applicable mortgage limits are increased by 20 percent to cover the costs of solar energy systems [59]. The loan incentive programs, however, only apply to systems "in conformity with such criteria and standards as shall be prescribed by the Secretary [of Housing and Urban Development] in consultation with the Secretary of Energy" [60]. 'I'hus, it is important for those in the wind energy industry to assist the Secretary in seeing that such "criteria and standards" are promulgated as soon as possible, and that they reflect current knowledge of wind machine performance. Once standards have been established, manufacturers must produce machines that can be warranted as meeting those standards [61]. 


\section{SECTION 3.0}

\section{SITING}

\subsection{ZONING}

Zoning is the most pervasive form of land use control in the United States. All states have zoning enabling legislation [62] and most communities of over 5000 population have enacted zoning ordinances. Zoning is usually a function performed by each political unit and reflects the values of the local citizens. In Euclid v. Ambler [63], the United States Supreme Court established zoning as a legitimate exercise of the police power to regulate for the public health, safety, and welfare. Zoning ordinances, like most legislative enactments, are presumed valid [64]; they will be overturned only when they are "clearly arbitrary and unreasonable, having no substantial relation to the public health, safety, morals, or general welfare" [65]. One who wishes to attack a zoning ordinance thus has a heavy burden.

The typical zoning ordinance provides for areas restricted to residential use, areas that permit commercial uses, and areas zoned for general industrial use. Because practically any use is permitted in an industrial area, WECS should meet no zoning problems there [66]. It is in residential and commercial areas that the zoning ordinances will cause the most problems for wind turbines. Most zoning ordinances say nothing about windmills. If windmills become common, specific zoning provisions can be expected. These may range from the simple addition of windmills to the list of accessory uses to which a landowner can put his property, to outright bans.

It has been held by the United States Supreme Court that: "The concept of the public welfare is broad and inclusive .... The values it represents are spiritual as well as physical, aesthetic as well as monetary. It is within the power of the legislature to determine that the community should be beautiful as well as healthy, spacious as well as clean ..." [67]. This statement has been used to support zoning on solely aesthetic grounds [68], a position [69] that most states nnw support.

Many who oppose wind machines consider them aesthetically unpleasing. This view can be given the force of law through the enactment of zoning legislation that prohibits wind machines on aesthetic grounds. Zoning legislation has been upheld that limits, on aesthetic grounds, the uses to which property may be put [70]. Wind machines may be successfully challenged under such statutes, especially if they are located in residential areas.

Wind machines can also be expected to conflict with the height restrictions commonly found in zoning statutes. There is an additional problem unique to wind machines: whether height is to be measured from the top of the tower or the top of the propellor arc [7l]. Considerations such as this point out the need for a model zoning ordinance for communities who wish to provide for use of wind energy machines [72]. It would be : useful to include in such an ordinance restrictions aimed at avoiding reckless WECS installation as a means of ensuring favorable public opinion.

The zoning issue for small wind machines is basically one of public acceptance. If a community chooses to exclude WECS it can legally do so. If a community wishes to permit or encourage WECS development it can remove any hinderances through simple amendment of its zoning oidinances. Some restrictions on WECS use are clearly 
justified, and local communities may need assistance in deciding how to draw a wind energy zoning ordinance.

Larger scale wind energy generating projects should encounter fewer problems with zoning. For the most part, they are likely to be sited far from zoned residential communities; to do so otherwise would be to invite liability, at least until WECS have been proven safe. Many states have power plant siting statutes for major utility facilities [73], that typically exempt qualifying facilities from local and land use controls [74].

There are various procedures to avoid the harsh impact of a zoning prohibition. Most common of these is a variance, usually granted only when there has been a showing of unnecessary hardship, a difficult burden to sustain [75]. Utilities regulated by the state public utility commission may be able to appeal local zoning decisions directly to the commission [76].

\subsection{GUARANTEED ACCESS TO WIND}

The power in the wind varies directly as the cube of its velocity [77]. This means that by reducing the wind speed by 50 percent, the energy that can be generated is reduced to one-eighth the original amount [78]. Even the seemingly slight reduction in wind speed from 10 miles an hour to 8 miles an hour results in a 50 percent reduction from the energy originally available. Therefore, it is of crucial importance for those who wish to generate electricity from the wind to be assured of a dependable supply of unimpeded air flow.

The legal issue surrounding guaranteed access does not involve conflicts with existing law, as in zoning, but rather the lack of any legal doctrine assuring a wind machine owner continued access to unimpeded wind flow over his property. A similar problem faces those who wish to install solar collectors [79]. Some writers see this problem as one which "may prove most troublesome for WECS promoters" [80], but one that cannot be fully evaluated until more technical data is available as to how long it takes the wind to recover lost power [81]. The wind recovers its speed from 5 to 10 rotor diameters after passing through a machine [82]. Läg'e-scale WECS develujei's will probably want to locate in remote areas far from any obstructions and purchase sufficient land to guarantee their wind flow. Clearly, ownership of the surrounding land is the best solution to this problem; unfortunately, this solution may be prohibitively expensive for small users. The task is to find a less costly way for small users to protect their air flow.

One proposed solution is the acquisition of negative easements over the property of adjoining landowners [83]. By use of a negative easement, the WECS owner can purchase the legal right to prevent the adjoining landowner from obstructing his wind flow [84]. Such an easement might drastically reduce the value of the adjoining land because of its reduced developmient potential. In this case the price for the easement would be high. Furthermore, because a wind machine must pivot to adjust to the direction of the wind, easements might have to be purchased in several directions.

The question arises as to whether a legal right to wind can be found or created. A muchcited state court decision, which precluded the existence of a common law right to sunlight, held that there is no authority for the proposition that "in the absence of some contractual or statutory obligation-a landowner has a legal right to the free flow of light and air across the adjoining land of his neighbors" [85]. England recognizes a right 
to sun and air through the Doctrine of Ancient Lights. The right created by the doctrine is not, however, to receive sun or wind of a commer cially usable intensity. The standard is instead based upon the ability to read without a lamp during the daytime. The doctrine is consequently not a persuasive basis for foreclosing the wind rights of commercial WECS [86].

Those that seek legal protection of their "wind rights" of ten make analogies to the rights secured by nonrenewable natural resources [87]. Though this makes for an interesting discussion, the analogies are for the most part inappropriate because wind is a renewable resource.

Some support does exist for those who seek to use the law of access to either water or sunlight as models for wind rights. The law of surface water has been suggested as an analogy for sun rights law [88]. New Mexico has recently implemented this idea in a statute that appears to present at least as many problems as it solves [89]. Water law is complicated [90] and not well suited to wind because it invokes different legal doctrines according to the scarcity or abundance of water in the region involved [9!]. An analogy to the emerging law of sun rights might eventually prove useful once case law and statutes define its parameters.

For example, in holding that there was no common law right to sunlight, one court left open the possibility of a statutory or contractual right [92]. A contractual right is probably too costly for the small developer. There remains the possibility of a statutory right to wind access that could be created by the legislature. If wind machines gain sufficient public support, a "wind rights" statute might be enacted. At present, however, insuring access to wind is the potential WECS developer's own responsibility.

Another possibility for establishing a right to wind can be found in the law of weather modification, where it has been held that a landowner has a natural right to the weather he would normally receive [93]. But this holding applies directly only to precipitation [94] and involves the interference with that right by a new and unexpected technology. Too many wind-obstructing structures have been built for the courts to hold that such construetion is illegal.

\subsection{NEPA AND OTHER FEDERAL AND STATE STATUTES}

The National Environmental Policy Act (NEPA) [95] mandates that all activities of the Federal Government be done in the least environmentally objectionable manner. Environmental impact statements must be filed for all ". . major federal actions significantly affecting the quality of the human environment" [96]. Each of these terms is construed liberally. "Major federal actions" include issuing a permit [97], making a loan [98], and proposing a budget [99], as well as more concrete actions [100]. An environmental impact statement (EIS) must address all "alternatives to the proposed action" [101]. Since most alternatives to a major wind energy power plant involve more environmental harm than the wind plant, the EIS requirement should raise no problems beyond the cost of the statement itself, which can be considerable [102]. A recent study by George Washington University suggests that "compliance with these statutes should require only the time and money necessary to comport with the procedure outlined in the statute" [103]. When the requirements of NEPA prove burdensome to a project deemed to be in the nation's best interest, Congress has shown a willingness to exempt that project from the requirements of the Act, as was done with the Alaskan pipeline [104]. 
Many states also have environmental policy acts [105]. These usually apply only to direct state action and not to state issuance of permits, such as permits for WECS devices.

An increasing number of states have state power plant siting statutes [106]. Typically, these apply only to power plants above a minimum size [107] and would not apply to small wind turbines. Some, such as California's [108], apply only to electricity generated from thermal or water power, probably because large-scale wind-powered electricity generation was not contemplated when the statutes were passed. If such large WECS become prevalent, amendments to the statutes can be expected.

Permits for power plant construction are either granted or denied depending upon the plant's compatibility with the state and local land use plans, environmental effects, and efficient utilization of natural resources [109]. The permit process should not create any undue hardships for carefully planned WECS use. WECS in coastal areas will have to comply with state coastal management statutes [110]. California, for example, requires permits to be issued by the Califnrnia Coastal Zone Commission for any devclopmcnt within 1,000 yards of the Pacific coastline [111]. It has been estimated that it now takes up to 18 months for a development in perfect compliance with California's coastal management scheme to receive the necessary permits. Some inland states have similar limitations on building on the shores of lakes and rivers [112] and in wetlands [113].

The Federal Government also regulates coastal areas and wetlands (as well as navigable waterways) under a permit program enforced by the Army Corps of Engineers [114]. The Corps may refuse to permit WECS development of wetlands if alternative sites are available [115].

The George Washington University Study [116] lists other federal statutes that may impact on wind turbine siting decisions. These are: the National Historic Preservation Act [117], (that will prevent WECS siting which detrimentally affects areas listed in the National Register of Historic Places) [118], the Federal Noise Control Act of 1973 [119] (that will prevent unduly noisy WECS), the Rare and Endangered Species Act of 1973 [12U] (that will prevent WECS from being sited in the migratory path of endangered birds; WECS having no significant detrimental effects on animals), the Federal Aviation Administration height standards [121] (that would regulate and perhaps ban WECS within 20,000 feet of an airport), and the Federal Communication Commission regulation of electromagnetic interference [122]. Congress can, of course, exempt particular projects from the impact of federal statutes if it wishes.

\subsection{OPFSHORE SITING OF WECS}

It has been suggested that large amounts of electricity can be generated by siting WECS off the seashore of the United States [123]. These suggestions presently are not feasible economically because of the high cost of building platforms that are sturdy enough to withstand storms and the problems of transmitting the electricity back to shore [124]. A large number of legal questions must be resolved before this use of offshore areas is possible [125]; e.g., the sale of power to onshore utilities, the impact of the recently enacted Public Utilities Regulatory Policies Act. [12,6], the allocation of liability for tortious conduct, and regulatory jurisdiction over offshore WECS. Moreover, as the distance from the United States shore increases, considerations of international law will also become important [127]. 


\section{SECTION 4.0}

\section{WECS OPERATION}

\subsection{BUILDING CODES}

The working group on "Institutional Barriers to WECS Growth" at the Third Wind Energy Workshop held in September 1977, found building codes to be the most cited single institutional barrier to WECS commercialization. "Building codes are probably the single most frequently mentioned barrier to [all] technological innovation in the construction industry." [128] Nevertheless, building codes will be a problem for wind turbines in the urban areas only where such codes exist. They should not severely affect the goal of significant wind power electrical generation, because most of that power will come from large arrays sited far from any urban area. These arrays, however, are still on the drawing board, while there are a number of manufacturers presently producing small wind turbines that could be used in an urban setting.

The main problem with building codes is that they vary tremendously from place to place, of ten without any discernible reason [129]. The present trend toward uniformity in state building codes may simplify matters somewhat [130]. The basic problem is the lack of a general consensus on what is desirable in a wind-oriented building code [13l]. It is clear that it will be several years before enough data is available to formulate a code; what must be developed now is a set of interim performance standards [132]. Many states condition their tax incentives, and recently the Federal Government conditioned eligibility for federally guaranteed loans [133] on the meeting of certain standards. An ongoing small wind turbine performance study being conducted at Rocky Flats, Colorado [134], will be helpful in meeting that goal but has generated little hard data to date. The development of product standards should be a prime concern to all who want to commercialize small wind turbines. These standards will help inspire public confidence, and will make comparisons between competing brands more meaningful.

Once sufficient technical data is available, a Uniform Wind Turbine Code could be formulated and circulated to municipalities and state legislatures. If building codes continue to be a significant problem, the Federal Government could probably preempt the field of wind turbine standards [135] as it has with mobile homes [136].

Despite all the discussion of building code problems, a small electricity generating wind turbine installed in New York found the building code provisions not at all burdensome [137]. The tower construction was regulated by the restrictions applicable to similar structures, such as cooling towers and T.V. antennas. The tower was required to be structurally sound, able to withstand the strongest foreseeable wind, and fire safe [138]. In addition, the electrical work had to be reviewed by a licensed electrician and the structural work signed by a licensed professional engineer [139]. The owners were visited by various inspectors but encountered no other problems [140].

\subsection{MACHINE FAUURE}

Many of the wind turbines being proposed today bear little resemblance to the innocuous, pastoral, midwestern windmill of $\mathbf{5 0}$ years ago. Machines are being proposed of up to 750 feet in height, and machines with rotors over 100 feet long are already in operation [141]. Understandably, people are curious as to how safe these machines are. These 
concerns are given added force by the fact that the first commercial power generating wind machine in the United States, Palmer Putnam's machine at Grandpa's Knob, Vermont, threw an 8-ton blade 750 feet in 1945 [142]. Under worst case conditions, a blade could land over 1500 feet from the tower [143]. A similar problem is the possibility of collapse of a supporting tower. Another situation that could give rise to liability is damage to a connecting utility's equipment from a malfunctioning cogenerating wind turbine. For example, a workm an could be killed or injured while working on utility lines if a WECS continued to feed electricity into the grid during a time when power was shut down to allow repairs.

Ultimately these issues may be resolved by technological improvements in the wind turbine system. For example, the synchronous inverter used to connect cogenerating WECS to the utility grid automatically disconnects during power outages so that a line worker [144] would be protected from electrocution. There is nothing particularly novel about the tower that supports a wind turbine, although the stresses put on a tower by a several hundred foot rotor may call for extra strengthening. NASA is presently conducting feasibility studies to determine whether a "fail-safe" belt or cable system could be used in the blades to prevent a thrown blade from traveling any significant distance [145]. The machines being built today all feather their blades in high winds and shut down completely when the wind reaches a certain level [146], so that even uncharacteristically high winds should not pose a serious problem.

Large wind machines and arrays of machines should be sited far away from places where a thrown blade could injure people or property. Such safety and siting requirements may take the form of city ordinances that regulate by setback requirements, tower length limitations, and blade specifications. For example, at the request of the Hanover, New Hampshire Planning Board, a Wind Turbine Committee was formed in late 1978 for the specific purpose of making recommendations on how to amend the town's zoning ordinances to permit the use of WECS. The Committee worked in conjunction with the Northeast Solar - Energy Center in Cambridge, Massachusetts, to develop a Zoning Ordinance Amendment with technical documentation. The conclusions and recommendations of the Committee are as follows:

- Permitted Use: WECS allowed as a permitted use by special exception.

- Safety/Setback: Setback requirements to protect public safety are provided.

- Tower Access: Tower climbing access should be limited.

- Tower Height: WECS allowed by special exception may exceed height regulations.

- Television Interference: WECS interference of television reception will be rare.

Noise: There will be no significant WECS noise beyond owner's property boundaries.

Aesthetics: Can be handled by Zoning Board of Adjustment when they consider the character of the area pursuant to the grant of a special exception for WECS. [1 47]

Nevertheless, accidents happen and someone has to pay for the damage that results. This is a concern to wind system manufacturers who may be liable under consumer protective products liability law, potential owners who are scared off by worries about their own liability, and neighbors of WECS owners who are worried about property and personal damage. 
The liability of a wind machine owner could be based either upon a theory of strict liability for carrying on an ultrahazardous activity or a theory of negligence. The general principle of the theory of strict liability is that "one who carries on an abnormally dangerous activity is subject to liability for harm to the person, land or chattels of another resulting from the activity, although he has exercised the utmost care to prevent the harm" [148]. Whether an activity is considered "abnormally dangerous" is of ten dependent upon its stage of technological development. Airplanes were considered abnormally dangerous during the early years of their operation [149], but are now considered so safe that it has been held that they do not normally crash in the absence of negligence [150]. Strict liability will be imposed upon an activity when there is the "existence of a high degree of risk" and an "inability to eliminate the risk by the exercise of reasonable care" [151]. Therefore, it will be important for the wind machine industry to show that a high degree of risk or harm can be avoided by the exercise of reasonable care.

Also important in deciding whether a person is to be held strictly liable for injuries that result from carrying on a particular activity is the "extent to which the activity is not a matter of common usage," and the "inappropriateness of the activity to the place where it is carried on" [152]. Thus, drilling an oil well in a residential area subjects the driller to strict liability [153]. Similarly, large-scale electrical generation from an array of wind $\mathrm{m}$ achines could be found inappropriate in a densely populated area. Even one wind machine could be abnormally dangerous if improperly and thoughtlessly sited (e.g., in an elem entary school yard).

A final factor in deciding whether an activity is ultrahazardous is "the extent to which its value to the community is outweighed by its dangerous attributes" [154]. The social value of wind power utilization will increase as fossil fuels become more expensive. If it is in the community interest to encourage an activity, the legislature can provide expressly that the activity is not ultrahazardous and the theory of strict liability cannot be used [155]. WECS owners most likely will not be held liable under the doctrine of strict liability [156], but care should be taken to see that WECS siting is not inappropriate to its surroundings.

The uller theory upon which the tort liability of a WECS owner might be based is negligence. Negligence has four elements: (1) a duty requiring the actor to protect others from unreasonable risks, (2) a breach of that duty, (3) an injury which is, (4) proximately caused by the breach [157]. A wind machine owner must operate his machine in such a manner as not to expose others to an unreasonable risk of harm. He owes this duty to any person who might foreseeably be injured by his breach of the duty. If such a person is injured, the owner/operator most likely will be liable. It is important to realize that the law of negligence puts no burden on the owner other than to act as a reasonably prudent person would in similar circumstances [158]. If reasonable people differ as to whether a person's conduct was negligent, the decision is made by a jury.

The Smith-Putnam Wind Turbine built on Grandpa's Knob, Vermont, serves as an example [159]. The operators knew that the blade skins had begun to break near the roots, making it necessary to reinforce that section. This section was "already a source of anxiety" to the operator because it was under great stress; the decision was made not to recast the blade, however, because of a wartime shortage of steel that would eventually mean a four-year delay in the project. The machine was kept in use despite the known defect, and the blade eventually broke and was thrown 750 feet, injuring no one. If people had been known to frequent that area and someone had been injured, it is likely that the operators wuld have been held liable. A more difficult question is raised where the 
person injured is a trespasser; i.e., on the land despite warning to stay off. The law in this area varies from state to state.

Manufacturers of wind machines have a duty to make their machines free from defects. The present law of products liability in most states is stated fairly accurately in the Restatement of Torts (2nd ed.) 402 A:

(1) One who sells any product in a defective condition unreasonably durigervus tu the user or consumer or to his property is sıbjest to liability for physical harm thereby caused to the ultimate user or consumer, or to his property, if

(a) the seller is engaged in the business of selling such a product, and

(b) it is expected to and does reach the user or consumer without substantial change in the condition in which it is sold.

(2) The rule stated in Subsections (1) applies although

(a) the seller exercised all possible care in the preparation and sale of his product, and

(b) the user or consumer has not bought the product from or entered into any contractual relation with the seller. [160]

This is an extremely broad base of liability. It makes the manufacturer liable to any unforeseeable bystanders who are injured by a defective product [161]. Strict liability also extends to the maker of a defective component part [162], a wholesale dealer [163], and a retail dealer [164]. To collect under this theory, all an injured party need show is that he has been injured by the product, that the injury occurred because the product was defective (as opposed to the injury being caused by, say, the injured party's own unreasonable behavior), and that the product was dcfective when it left the defendant's hands. No proof of negligence is necessary. The manufacturer's care is no defense.

The American Wind Energy Association is concerned that these doctrines might frighten prospective manufacturers and especially retailers out of the wind turbine market. They would like to see a federally imposed limit on manufacturers' and retailers' liability in the case of blade throwing or tower collapse [165]. The Price-Anderson Act [166] imposed a limit on liability from accidents at federally licensed nucleur power plants. The constitutionality of such a limit was recently upheld by the Supreme Court [167]. In holding that the limit did not violate the constitutional guarantees of due process and equal protection the Court said: "the need for the imposition of a statutory limit on liability to encourage private industry participation ... bears a rational relationship to Congress' concern for stimulating the involvement of private enterprise in the production of electrical energy ... (through the use of nuclear power)" [168]. It must be noted that our commitment to nuclear power is much greater than our present commitment to wind power and the fact that such a bill is constitutionally permissible does not make its enactment probable. An alternative solution might be some form of government-funded low-cost product liability insurance for WECS manufacturers and retailers whose products meet certain standards. 


\subsection{ENVIRONMENTAL CONCERNS}

Some writers have expressed concern that environmental effects might impede WECS development. Discussion of these effects to date has been primarily theoretical (the few large WECS operating present no empirical cause for environmental concern). The Environmental Protection Agency (EPA) suggests that the operation of one wind machine presents no particular environmental problem, but expresses concern that the cumulative effect of a large array of such machines might be more significant [169]. Batelle Laboratories suggests that to insure maximum efficiency and prevent "wind-robbing," the individual machines in a large array must be spaced sufficiently far apart. The environmental effects of an array can be determined by observing a single machine [170].

\subsubsection{Microwave Interference}

The rotating metal blades of a windmill can produce video distortion of television reception [171]. The distortion is worst on the upper uhf channels and "in the worst cases," where the wind machine is located directly between the broadcaster and receiving antenna, "can extend for distances up to a few miles" [172]. This distortion can be partially avoided by using nonmetallic blades [173]. Research is being conducted to investigate the possibility of using blades fabricated from wood and prestressed concrete [174]. Where siting options are available the problem can be avoided by proper siting.

There is authority to the effect that a landowner has no legal right to continued uninterrupted reception of television signals [175]. Those whose television reception was to be obstructed by the Sears Tower in Chicago sought to enjoin construction of the tower, but the court denied their petition, stating that "disruption of television signals initiated by totally independent third parties over which defendant has no control cannot be the basis for enjoining the full legal use and enjoyment of defendants' property" [176]. If wind energy machine arrays are located so that whole communities find their reception distorted, the WECS owner might be compelled to construct a relay station for the radio waves which, would avoid the problem.

\subsubsection{Climate Modification}

Some commentators feel that large arrays of wind machines may produce modifications of the local climate [177]. These modifications are, however, expected to be slight. In the case of an adjoining landowner who is aggrieved by a lack of precipitation there is authority that, "the landowner is entitled to such precipitation as Nature deigns to bestow" [178]. This case dealt, however, with intentional weather modification. One law review writer reports that "no cases have yet dealt with inadvertent modification" [179]. Despite this absence of case law there are a number of full-length studies [180], which may be borrowing trouble that most likely will never arise.

\subsubsection{Noise}

It was once thought that electrical power generation from windmills, especially from a large number of windmills, would create enough noise to subject the operators to nuisance claims. This belief has since been discredited. The Environmental Protection Agency states that, "Only a quiet swishing sound can be heard when one stands under a 15-meter propeller-type rotor". [181]. Furthermore, the noise from large wind farms should be no worse than that from a single machine [182]. 


\subsubsection{Aesthetics}

Most writers agree that, "the impact of the row of wind machines on the appearance of the landscape is probably the most important adverse environmental effect" [183]. This belief alone may be sufficient to keep wind machines out of areas with zoning ordinances [184]. Large arrays of wind machines could be found so offensive that public pressure would demand the discontinuance of their use. More likely, if the large WECS are sited appropriately to minimize their adverse aesthetic impact, the public will come to accept them as they presently accept high tension lines and the like. A study done for the National Science Foundation by the University of Illinois Survey Research Laboratory [185] indicated that the public is willing to tolerate some aesthetics impact as a cost of energy which is nonpolluting and can be "homegrown" rather than imported. This study also indicates that the public has decided preferences about which designs of wind turbines they find most offensive. While a balance must be struck between aesthetic and efficiency, WECS developers should keep an eye on what the public desires when designing and siting large wind turbines.

Landowners can enforce their aesthetic views through zoning or, in the case of subdivisions, through mutually restrictive covenants that may estahlish an architeotural rovicw board or similar controls. In the absence of some uniform regulation, landowners cannot enjoin the construction of a windmill just because they do not like the way it looks. An action for nuisance cannot be based on aesthetics alone [186].

\subsubsection{Bird Collisions}

Wind turbines may create a hazard for passing birds. Battelle Laboratories has done some theoretical calculation on how many birds would be killed by a WECS if the birds took no evasive action [187], but reports that there has been no empirical verification [188]. Most migratory birds fly too high to come into contact with WECS. The possibility of bird kills presents a legal problem only when a rare and endangered or otherwise regulated species is involved [189]. Such conflicts can usually be avoided by appropriate siting decisions. 


\section{SECTION 5.0}

\section{CONCLUSION}

The rising cost of fossil fuels has once again made wind generation a viable energy alternative. But before large-scale WECS development can occur, a number of legal and institutional issues must be resolved. A critical area of concern will be the creation of financial incentives. Likewise, unless access to wind energy can be guaranteed and liability predicted, potential investors will remain understandably hesitant to finance WECS systems. But perhaps the greatest barrier to WECS development is, and will remain, public acceptance. Until the American public decides that wind is a desirable generation source, and pressures its legal and economic institutions to adjust accordingly, the power of the wind will remain a potential, but essentially untapped, energy alternative. 
THIS PAGE INTENTIONALLY LEFT BLANK 


\section{REPERENCES}

1. Palmer Putnam, Power From the Wind 17 (1948).

2. D. Brunt, Physical and Dynamic Meteorology 287 (1941).

3. Supra note 1, 209.

4. Ramakumar, Allison, Hughes, "Solar Energy Conversion and Storage Systems for the Future," IEEE Transactions on Power Apparatus and Systems, Vol. PAS-94, no. 6, 1926, 1929, November/December 1975.

5. ERDA, Wind Energy Mission Analysis, Executive Summary 1 (COO/2578-1/1) (1977).

6. Id. Other estimates range to 1.5 trillion and higher. Supra note 4 at 1927. However, some of these estimates are unrealistically based on honeycombing every available square foot of the nation with wind turbines. Also, these figures do not include energy contained in the wind over the territorial waters and high seas, the development of which is currently impractical. For discussion of this topic, see William Heronemus, "Power from the Offshore Winds," Proceedings of the 8th Annual Marine Technology Conference (1972).

7. Joseph M. Savino and Frank R. Eldridge, Special Report on Solar Energy 53 (1975).

8. L. Soloman and F. Riesmeyer, The Development of Alternate Energy Sources: A Legal and Policy Analysis, 30 Okla. L. Rev. 319 (1977).

9. Id. at 319 .

10. See, e.g., The Clean Air Act, 42 U.S.C. 7401 et seg. (as amended).

11. 42 U.S.C.A. SS 5551-5556.

12. Id. at $\$ 5551$ (b).

13. Id. at $5552(\mathrm{a})(1)$.

14. Executive Office of the President, Encrgy Policy und Plunning, National Energy Plan 76 (1977).

15. National Energy Conservation Policy Act, Pub. L. 95-619, 92 Stat. 3206, \$\$ 212(c) and $210(11)(\mathrm{H})(1978)$.

16. Supra note 5 Wind Energy Mission Analysis 1 .

17. See generally Frank Eldridge, MITRE Corp. Wind Machines (NSF RANN-75-051) for an overview.

18. The terms "wind machine," "windmill," "wind turbine," and "WECS" will be used inter changeably in this paper.

19. See note 7 supra.

20. Cal. Penal Coile $\$ 502.1 / 2$ (West 1070).

21. Fla. Stat. Ann. $\$ 713.63$ (West 1976).

22. Tex. Rev. Civ. Stat. Ann. art. 5462 (Vernon Supp. 1976-77).

23. Neb. Rev. Stat. $\$ 17-529$ (1974).

24. See, e.g., N.J. Stat. Ann. (1960) 54:4-3.113.

25. Note 7 supra. 
26. See, e.g., Ward v. Norton, 86 Kan. 906, 122 P.881 (1912).

27. This is the position taken by Howard and Rita Tanbenfeld in their article, "Wind Energy Legal Issues and Legal Issues and Legal Barriers"-Southwestern Law Review 1053.

28. Survey Research Laboratory, University of Illinois, Public Reactions to Wind Energy Devices (1977).

29. MITRE, Proceedings on the Second Workshop on Wind Energy Conversion Systems (RANN Serial No. NSF-RA-N-75-050 MTR-6970) (1975).

30. Id. at 472 .

31. See Jan Laitos and Randall Feuerstein, "Regulated Utilities and Solar Energy: A Legal-Economic Analysis of the Major Issues Affecting the Solar Commercialization Effort," 56 University of Denver Law Journal, 31 (1979); Laitos, Public Policy Questions Posed by the Rise of a Solar Energy Industry in Colorado, CERI Report, April 1878.

32. Charles A. Lindley, 2 Wind Machines for the California Aqueduct, Final Report (SAN/1101-76/2) (1977) finds wind machlnes competitive with new coal and nuclear plants. As fossil fuel prices rise,-that of oil became of scarcity; that of coal, became of the expense of Instulliny costly scrubbers to remove sulfur oxides, wind will become more competitive.

33. See generally Department of Energy, Solar Energy Incentives Analysis: PsychoEconomic Factor Affecting the Decision Making of Consumers ( $\mathrm{HCP} / \mathrm{M}-2534-01)$ (1978).

34. Id.

35. The Program of Policy Studies in Science and Technology, Geurge Washington University, Legal-Institutional Implications of Wind Energy Conversion Systems (WECS) (1977) (NSFIR A-770203) [hereinaf ter cited as G.W. Study] at 137 note 5.

36. The faster WECS are accepted on the marketplace, the sooner they can be massproduced, which is the key step to eventual economic viability. See Wind Energy Mission Analysis, supra note $b$ for a discusslon of tlet effect of rutc of loarning curvo ul timate use.

37. See Energy Policy Project, National Conference of State Legislatures, Energy Report to the States, Summary of State Solar Legislation 1974-76 8-15 (1977).

38. See, e.g., C.R.S. $\$ 39-22-113$ (4) (c).

39. See, e.g. Hawaii Rev. Stat. 235-12.

40. 81 Ann. Code of Md. (1969) 14 (b) (4) [as amended.

41. N.J.S.A. (1960) 54:4-3.113 [as amended.

42. Ariz. Stat. Ann. (1956) 43-123.37 (e).

43. The Federal Government has a similar requirement.

44. Calif. Rev, and Tax Code $\$ 17052.5$.

45. Booz-Allen and Hamilton, Inc., The Effectiveness of Solar Energy Incentives at the State and Local Level, (PB-2 $\overline{63} 371)(1976)$.

46. See Department of Energy, Federal Wind Energy Program, Program Summary 20 (January 1978) (AOE/ET-002 $\overline{3 / 1)}$. 
47. Pub. L. 95-618; 92 Stat. 3178 (Nov. 16, 1978).

48. Id. at $\$ 101$, amending subpart A of part IV of subchapter A of Chapter 1, by inserting new $\$ 44 \mathrm{C}$ (c) (5) (A)(ii).

49. Id. at $\$ 101$, of new $\$ 44 \mathrm{C}(\mathrm{b})(2)$.

50. Id. at $\$ 101$, of new $\$ 44 \mathrm{C}(\mathrm{b})(6)$.

51. A group in New York City installed a 2 kilowatt wind turbine for a total hardware cost of about $\$ 4,200$. That machine proved economical to install and run including finance charges. See, Energy Task Force, Windmill Power for City People 38-42 (1 977) for a small WECS cost/benefit analysis.

52. Supra note 47 , at Title III.

53. Id. at $\$ 301$, am ending $\$ 46$ (a) to include $\$ 46(\mathrm{a})(10)(\mathrm{c})$.

54. Id. at $\$ 301$, amending $\$ 48$ by adding $\$(e)(2)(\mathrm{A})(\mathrm{ii})$.

55. Some states' income tax incentives provide that they are reduced dollar for dollar by the amount of any federal tax credit, e.g., Calif. Rev. and Tax Code $\$ 17052.5$, but such measures are uncommon.

56. Pub. L. 95-619, 92 Stat. 3206 (Nov. 9, 1978).

57. Id. at $\$ 241$.

58. Id. at $\$ \$ 245,246$.

59. Id. at $\$ 248$.

60. Id. at $\$ 241$.

61. See G.W. Study supra note 35 , at $135-159$, for a discussion of how typical financing strategies; securities, depreciation, SBA loans and the like might be extended to WECS.

62. N. Williams, American Planning Law $\$ 18$ (1974).

63. 272 U.S. (1076).

64. Golden v. Planning Board of Ramayso, 3 N.Y. ed 359, 334 N.Y.S. 2d 138, 285 N.E. 2d 291, App. denied 409 U.S. 1003.

65. 272 U.S. at 395 .

66. 272 U.S. at $380-1$.

67. Berman v. Parker, 348 U.S. 26, 33 (1954).

68. N. Williams, American Planning Law $\$ 11$ (1974). There are a few states where aesthetic appeal alone is not sufficient ground to uphold a zoning ordinance. See, e.g., Metromedia, Inc. v. City of Des Plaines, 26 Ill. App. 3d 942, 326 N.E. 2d 59 (1975) or Mayor of City Council of Baltimore v. Mano Schwartz, Inc., 299 A. 2d 828 (Md. 1974). Even there, the case for windmills would be hard to sustain since aesthetics and something else. is permissable as a basis for a zoning decision. The something else could be fear of injury from the windmill, which the legislature might rationally conclude to be a threat to the public health.

69. Id.

70. People v. Marion A. Stover, 12 N.Y. 2d 462, 240 N.Y.S. 2d 734, 191 N.E. 2d 272 (1963) appcal diemissed 3/5 i. i.s. 42 (1963). 
71. G. W. Survey, supra note 35 at 75 . There is also a question of whether setbacks should be measured from the lower footing, leg, or guy wire.

72. See New Mexico Energy Institute, A Proposed Solar Zoning Ordinance (1977) for such an ordinance for protecting solar rights. See also, Sandy F. Kraemer, Solar Law: Present and Future with Proposed Forms. (1978).

73. Ohio Rev. Code Ann. $\$ 4906.01$ et seg. (Page Supp. 1975).

74. Id. $\$ 4906.13$.

75. R. Anderson, 2 American Law of Zoning $\$ 14.16$ (1968).

76. See, e.g., Ind. Code Ann. $\$ 8-1-2-101$ (Burns 1973).

77. P. Putnam, Power from the Wind, 15 (1948).

78. Id.

79. This topic has been a very fertile field for article writers and most of the existing litelatul'te concerns "sun rights" and ways to protect them. See, e.g. "Solar Rights: Guaranteeing a Place in the Sun," 57 nregon Law Rcview 94-134 (1977), "Sular Kightits Loning Guarantee," 1976 Wash. U. Law Q. 375-402 (Summer 76), "Solar Rights and Their Effect on Solar Heating and Cooling," 10 Nutural Resour ces Journal 363-414 (April 1976).

80. G.W. Survey supra note 35 at 100 .

81. Id.

82. S.E. Rogers, et al., Evaluation of the Potential Environmental Effects of Wind Energy System Development (ERDA/NSF/07378-75/1) (August 1976). Ms. Rogers has suggested that the distance is probably closer to five rotor diameters.

83. 1973 Colo. Rev. Stat. $\$ \$ 38-32.5-101,102$ recognizes and makes legally enforceable easements guaranteeing a continued access to sunlight. Such legislation might prove helpful to wind owners.

84. See generally Rowell and Rohan, Powell on Real Property, chapter 34 (1968). Some discussion has been made with respect to solar rights that prescriptive easements might be of some use. These easements usually require 20 years to vest and thus do not give the would-be installer the necessary certainty. Also, negative easement can never be created by prescription.

85. Fontainebleau Hotel Corp. v. Forty-Five Twenty-Five, Inc., 114 So. 2d 357 (1959).

86. See generally H. Cox, Law and Science of Ancient Lights (2nd ed. 1871).

87. The law is perhaps most clear regarding the legal rights of those who have oil and gas interests. See, e.g., Hemingway, The Law of Oil and Gas (1971).

88. White, "The Allocation of Sunlight: Solar Rights and the Prior Appropriation Doctrine," 417 Univ. Colo. L. Rev. 421, (1975/76).

89. Ch./169, 1977 N.M. Laws.

90. See generally F. Trelease, Cases and Materials on Water Law (2nd ed. 1974).

91. See U.S. D.O.E., Legal Barriers to Solar Heating and Cooling of Building 26-29 (March 1978) for a discussion of why water law is not an appropriate analogy to sun rights. These argum ents apply with more force to wind. 


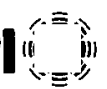

92. Note 85 supra.

93. Southwestern Weather Research Inc. v. Rounsaville, (Ct. Civ. App. Tex. 1958) 320 S.W. 2 d 211 .

94. Id. at 216; "the landowner is entitled to such precipitation as Nature deign to' bestow."

95. 42 U.S.C.A. \$\$ $4321-4347$.

96. Id. at $4332(2)$ (c).

97. Ely v. Velde, 451 F.2d 1130 (4th Cir. 1971).

98. Texas Comm. on Natural Resources v. U.S., 2 ELR 20574 (W.D. Tex.), vacated as moot 430 F.2d 1315 (5th Cir. 1970).

99. Sierra Club v. Morton, 395 F. Supp. 1187 (D.C.D.C. 1975).

100. See generally F. Anderson, NEPA in the Courts: A Legal Analysis of the National Environmental Policy Act (1973).

101. 42 U.S.C.A. $\$ 4332(2)$ (c) (iii).

102. For an excellent discussion of wind energy and NEPA see Phillips, NEPA and Alternative Energy: Wind as a Case Study, l Solar L. Rep. 29 (1979).

103. Supra note 27 at 87, citing Council on Environmental Quality, Annual Reports [1971-1976] at 634-640 for estimates of the amount of money and time required to complete the environmental impact policy.

104. Trans-Alaska Pipeline Authorization Act. Pub. L. 93-153, Tit. II, 87 Stat. 584.

105. See, e.g., Cal. Pub. Res. Code \$\$ 21000-21174; Conn. Gen. Stat. Ann. Ch. 439 \$22a-1 et seq.; Ann. Laws Mass. Ch. 30, \$\$ 61-62.

106. See, e.g., Ohio Rev. Code Ann. $\$ 4906.01$ et seg.

107. Id. at $\$ 4906.01$ (b) (1) (minimum SOMW).

108. Cal. Pub. Res. Code $\$ 25110$.

109. See, e.g., Conn. Gen. Stat. Ann. $\$ 16-50$ p (a).

110. See, e.g., Ċal. Yub. Kes. Code \$\$ 30,000-900, Del. Code title $7 \$ \$ 7001-7013$.

111. Id. Cal. Pub. Res. Code.

112. See, e.g., Wisc. Stat. Ann. $\$ \$ 59.971,144.66$.

113. See, e.g., Main Rev. State, title 38, $\$ \$ 471-478$.

114. Rivers and Harbors Act of 1899, 33 U.S.C.A. $\$ 401$ et seg.

115. 33. C.F.R. $\$ 209.120$ (g) (3) (iv) (a). The Federal Coastal Zone Management Act of 1972 merely provides financial assistance for state coastal zone management plans. 16. U.S.C.A. $\$ 1451$ et seq.

116. Supra note 35 .

11.7. 16 U.S.C. $\Lambda . \$ 470-470 \mathrm{~m}$ (1974).

118. 36 C.F.R. $\$ 60.6$.

119. 42 U.S.C.A. $\$ 4901$ et seq. (1973).

120. 16 U.S.C.A. $\$ 1531-1543$ (1973). 
121. 14 C.F.R. Part 77 (1976).

122. 47 C.F.R. Part 15 (1976).

123. W. Heronmus, "Power from the Offshore Winds," Proceedings of the 9th Annual Marine Technology Society Conference (1977).

124. E. Wendell Hewson, a presentation made by invitation to the Subcommittee on Environment and Energy, Joint Interim Committee on Environmental, Agricultural and Natural Resources at The State Capital, Salem, Oregon on April 1 1, 1974.

125. See generally Louis Mayo, Legal Institutional Arrangements Facilitating Offshore Wind Energy Conversion Systems (WECS) Utilization, DOE/NSF/19137-77/3 (1977) for a treatment of the problems that will arise and (as the title suggests) some tentative solutions. See, also, Rita and Howard Taubenfeld, "Wind Energy: Legal Issues and Legal Barriers", S.W. Law Review 1053, 1062-8 (1977) for an overview and G.W. Survey, 216-260 supra note 34 .

126. See Title II of P.L. No. 95-617, 92 Stat. 3117 (1978).

127. See Nanda, Ocean Thermal Energy Conversion (OTEC) Development Under U.S. and International Law and Institutions, 56 Denver L.J. '23y ( $\left.1 y^{\prime} / y^{\prime}\right)^{\prime}$.

128. Schoen, Hirshberg, Weingart, New Energy Technologies for Buildings, Institutional Problems and Solutions. 171 (J. Stein ed.)(1975).

129. See "A Decent Home", Keport of the Yresident's Lommittee on Uriban Housing. U.S. Government Printing Office D 313-937 (1969) for a jurisdiction by jurisdiction survey of building codes.

130. New Energy Technologies, supra note 135 at 91.

131. Wind Workshop, supra note 134 at 898-902.

132. Id.

133. See Section $\Pi$, Financing, supra.

134. R. L. Moment, Systems Development and Test Center Activities in the Wind Systems Program at Rocky Flats, RFP-2698, (1978).

135. See Field and Rivkin, The Building Code Burden "A Legal Basis for Federal Action" (1975) for a discussion of probable federal authority.

136. 42 U.S.C.A. 5401 et seq.

137. Energy Task Force, Windmill Power for City People 18 (1977).

138. Id.

139. Id. at $18,29$.

140. İd. at 29.

141. Frank Eldridge, Wind Machines, NSF-RA-N-75-051, (1975).

142. P. Putnam, Power from the Wind 131-3 (1948).

143. ERDA, Solar Program Assessment, Environmental Factors, Wind Energy Conversion, (ERDA 77-47/6) 28 (1977).

144. Energy Task Force, Windmills for City People 35 (1977).

145. Solar Program Assessment, supra note 150 at 29. 
146. Wind Machines, supra note 148 at 30 . The first large scale WECS, built by ERDA at Plum Brook, Ohio, completely feathers its blades at wind speeds over 60 miles an hour and is designed to withstand wind velocities as high as 150 miles an hour.

147. Executive Summary of WECS Zoning Amendment Ordinance, Town of Hanover, New Hampshire (1978).

148. 3 RESTATEMENT OF TORTS 2d \$ 519(1) (1977).

149. Rochester Gas and Electric v. Dunlop, 148 Misc. 849, 266 N.Y.S. 469 (1933).

150. See Cox v. Northwest Airlines, Inc., 379 F. 2 d 893 cert. denied, 389 U.S. 1044 (1967) where the airlines liability was predicated on the tort theory of res ipsa loguitur (See PROSSER, LAW OF TORTS, 4th ed. $\$ \$ 39,40$ (1971) for a discussion of res ipsa loquitor).

151. 3 STATEMENT OF TORTS $2 \mathrm{~d} \$ 520$ (a) (c) (1977).

152. Id. at $\$ 520(d)$ (c).

153. Green v. General Petroleum Corporation, 205 Cal. 328, 270 P. 952 (1928).

154. 3 RESTATEMENT OF TORTS 2d 520(f) (1977).

155. See, e.g., Texas Code Ann. WATER $\$ 18.152$ where the statute provides that one who engages in weather modification pursuant to a state license and permit is not to be held strictly liable for any resulting damages.

156. This view is shared by the authors of the G.W. Survey supra, note 35 at 164 .

157. Prosser, The Law of Torts, 4 th ed. (1971) $\$ 30$.

158. Id. $\$ 31$.

159. P. Putnam, Power from the Wind, 12-14 (1948).

160. 2 RESTATEMENT OF TORTS (2nd ed. 1971) $\$ 402 \mathrm{~A}$.

161. See Goberson v. Ford Motor Company (Mo. 1974), 504 S.W. 2d 8 and cases cited therein.

162. Rosenau v. City of New Brunswick, 51 N.J. 130, 238 A. 2 d 169 (1968).

163. Barth v. B.F. Goodrich Tire Co., 265 Cal. App. 2d 228, 71 Cal. Reptr. 306 (1968).

164. Housman v. C.A. Dawson and Co., 106 Il. App. 2d 225, 245 N.E. 2d 886 (1969).

165. Rick Katzenburg and Ben Wolff, The Federal Wind Progrum: A Proposal for the FY70 Budget, p. 13 (1978).

166. Atomic Energy Act of $1954, \S 170$ as amended 42 U.S.C.A. $\$ 2210$. The limit, $\$ 560,000,000$, demonstrated the much large extent of our country's commitment to nuclear energy.

167. Duke Power Co. v. Carolina Environmental Study Group, Inc. Ct. 2620 (1978).

U.S. , $98 \mathrm{~S}$.

168. Id. at 2637 .

169. EPA, Development Status and Environmental Hazards of Several Candidate Advanced Energy Systems (June 1977).

170. Sharon Rogers, Battelle Columbus Laboratories, Columbus, Ohio, personal communication, August 1978. Ms. Rogers the ERDA report, An Evaluation of the Potential Environmental Effects of Wind Energy System Development (ERDA/ NSF/07378-75/1). 
171. T.B.A. Senior, D.L. Sengupta, J.E. Ferris, TV and FM Interference by Windmills (COO/2846-76/1) (1977).

172. Id. at 11 .

173. Id. at 12 .

174. DOE, Federal Wind Energy Program, Program Summary Junuary 1978 (DOE/ET0023/1) 39-40.

175. People ex rel Hoogasian v. Sears, Roebuck and Co., 52 Ill. 2d 301, 287 N.E. 2d b77 (1972) cert. denied 409 U.S. 1001 .

176. Id. at 679 .

177. Mark Davidson, Donald Grether and Kenneth Wilcox, Ecological Considerations of the Solar Alternative (NTIS) (1977) at B-22 ("Climate Modification Appears Posciblo") Wallace Howell, Fnvirnnmental Impact of Large Wind Power Farms (1977) (Unpublished paper, Burcau of Roolamation, Lienver, rnlnrarn) Tsime very minor modification of the local climate).

178. Southwest Weather Research Inc., v. Rounsaville, (Ct. Civ. App. Tex. 1958) 320 S.W. 2d 211 at 216 .

179. A. G. McKenzie, "Weather Modification: A Review of the Science and the Law", 6. ENVIRONMENTAL LAW 386 (1976) at 403.

180. See "Who Owns the Clouds", 1 Stanford Law Review 43 (cited with approval in Southwest Weather, supra note 190).

181. EPA, Development Status and Environmental Hazards of Several Candidate Advanced Energy Systems, EPA-600/7-77-062 (1977).

182. W. E. Howell, Environmental Impact of Large Wind Power Farms (Unpublished paper, Bureau of Reclamation, Denver, Colorado) 9 (1977).

183. Lindley, 2 Wind Machines for the California Aqueduct, (1977) at 155 (SAN/110176/2). See also Mark Davidson, et al., Ecological Considerations of the Solar Alternative (1977) at B-23.

184. See Section III. A. supra.

185. NSF, Public Reactions to Wind Energy Devices (1977).

186. See 84 ALR. 2d 653, $658 \$ 4$ and cases cited therein.

187. Rogers, et al., Evaluation of the Potential Environmental Effects of Wind Energy Systems Development (1976).

188. Id. The 100 kilowatt wind machine at Plum Brook, Ohio, has reported only one dead bird.

189. See, e.g., Lindley, 2 Wind Machines for the Calif ornia Aqueduct (1977), where the problems raised by siting wind machines near nesting grounds of the endangered condor are discussed. 